\title{
LATE HOLOCENE ENVIRONMENTAL RECONSTRUCTION OF ST. MICHIEL SALINE LAGOON, CURAÇAO (DUTCH ANTILLES)
}

\author{
Bogumila B Klosowska ${ }^{1,2} \bullet$ Simon R Troelstra $^{1} \bullet$ Jan E van Hinte $^{1} \bullet$ Dirk Beets $^{1} \bullet$ \\ Klaas van der Borg ${ }^{3}$ A Arie F M de Jong ${ }^{3}$
}

\begin{abstract}
Two sediment cores collected from the saline lagoon St. Michiel on Curaçao (Dutch Antilles) preserve a $\sim 5000$-yr record of environmental change. Investigation of radiocarbon-dated sections by accelerator mass spectrometry (AMS) is based on faunal assemblage analyses, sediment mineralogy, and the interpretation of sedimentary facies. The cores recovered from different parts of the lagoon demonstrate different development. Initially, in the proximal part of the lagoon (core STM-2), the sediment accumulated in a coastal, semi-protected bay with strong marine influence, whereas the distal part (STM-1) was dominated by chemical precipitation (gypsum, aragonite). By about 3500-3400 BP, connection with the open sea became very limited due to the gradual formation of a coral rubble barrier at the coastline. Subsequently, the record reveals undisturbed sedimentation in the highly restricted shallow lagoon. Around 1100-1000 BP, biological and sedimentological records indicate a change to less evaporitic conditions. Stages of increased salinity are intercalated with intervals of episodic freshening due to increased runoff and precipitation. The authors demonstrate that since permanent human settlements were established on the island about $1100 \mathrm{BP}$, the watershed has undergone intensive deforestation, especially during the European colonization at the beginning of the 16th century. Deforestation resulting from agriculture and construction caused increased erosion, which was translated to increased sediment accumulation rates and a shift in lagoon sedimentation from almost entirely endogenic to mostly detrital.
\end{abstract}

\section{INTRODUCTION}

Saline lagoons are common features in arid and semi-arid areas. They respond quickly to environmental change; therefore, their sedimentary record can provide a very sensitive archive of past fluctuations in water chemistry, hydrology, and drainage basin characteristics. In this study, we investigate the late Holocene sedimentary sequence of a saline lagoon of Curaçao, one of the Leeward Islands of the Dutch Antilles. It is based on faunal assemblage analyses, sediment mineralogy, and the interpretation of sedimentary facies of 2 shallow cores.

St. Michiel salina is one of a number of shallow ( $<2 \mathrm{~m}$ average depth) coastline lagoons of Curaçao, separated from the open sea by an approximately 50 -m-wide, slightly elevated ridge of coral debris (Figure 1). A very narrow canal (2-3 m wide) cuts the ridge and connects the lagoon with the Caribbean Sea. Bedrock in the area consists of Cretaceous volcanic rocks and Neogene and Quaternary limestones (Beets 1972; De Buisonjé 1974; Klaver 1987; Fouke 1994). The northern parts of the lagoon, most distant from the sea, overlie deeply weathered hyaloclastites and dolerites of the Curaçao Lava Formation, which in a seaward direction are unconformably overlain by more resistant calcareous and dolomitized rocks of the Seroe Domi Formation (Figure 1).

The saline lagoons of Curaçao are essentially shallow remnants of former inland bays. Formation of these coastal embayments is related to eustatic sea-level rise after the last glaciation. In the Pleistocene, when the sea level was lower than today, systems of erosional drainage basins were formed which, in the periods of postglacial transgression, developed into inland bays and lagoons (De Buisonjé 1974).

\footnotetext{
${ }^{1}$ Faculty of Earth and Life Sciences, Department of Paleoecology and Paleoclimatology, Vrije Universiteit, de Boelelaan 1085, 1081HV Amsterdam, the Netherlands.

${ }^{2}$ Corresponding author. Email: klob@geo.vu.nl.

${ }^{3}$ Robert J van der Graaff Laboratorium, University Utrecht, Box 80.000, 3508 TA Utrecht, the Netherlands.
}

(C) 2004 by the Arizona Board of Regents on behalf of the University of Arizona Proceedings of the 18th International Radiocarbon Conference, edited by N Beavan Athfield and R J Sparks RADIOCARBON, Vol 46, Nr 2, 2004, p 765-774 

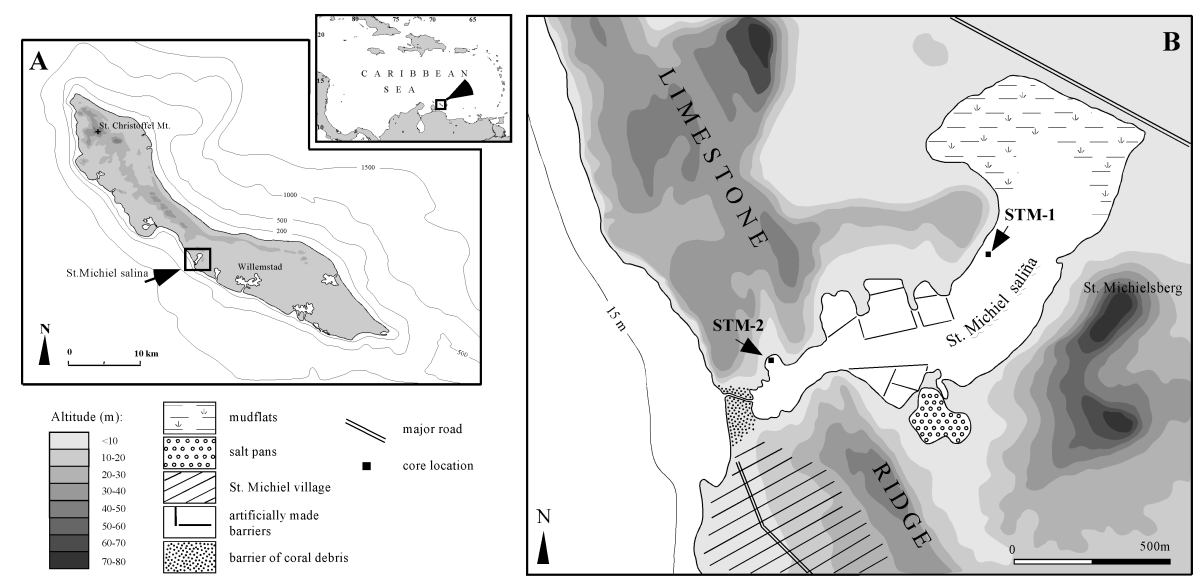

Figure 1 a) Map of Curaçao and the location of saline lagoon St. Michiel. Bathymetry in meters. b) Map of St. Michiel saline lagoon and surroundings with the coring sites. Elevated terrains consist of more resistant limestones of Seroe Domi Formation.

The area experiences a semi-arid climate with a mean yearly temperature of about $27^{\circ} \mathrm{C}$; the mean relative air humidity is about $75 \%$ and mean annual precipitation is around $550 \mathrm{~mm}$, although there is usually large variability between years (Martis et al. 2002). Curaçao is situated in the belt of trade winds from the east and east-northeast. Although the island is located south of the Atlantic hurricane belt, occasionally tropical storms pass within $200 \mathrm{~km}$ of the island and cause heavy damage in the shallow coastal areas (Meteorological Service: http://www.meteo.an). The average daily tidal range on Curaçao is approximately $30 \mathrm{~cm}$. However, due to its restricted connection to the sea, the lagoon is an area of limited tidal flow. Salinity of the water in the lagoon is primarily controlled by the balance between rainfall and evaporation, by the inflow through the canal, and by seepage. The salinity fluctuates on an irregular basis depending on the amount of rainfall, from brackish conditions after heavy rainfall to hypersaline conditions after prolonged drought.

The pre-colonization history of the island is poorly known, but archaeological evidence indicates the presence of permanent settlements in the area about 1100 BP (Versteeg and Rostain 1997). The original inhabitants were Caquetíos Indians who migrated from the coastal regions of the South American continent. They lived primarily from fishing and agriculture. Since the arrival of Europeans in AD 1499, Curaçao was subjected to 1 century of Spanish rule and came under Dutch control in AD 1634. Rapid growth of the population, woodcutting for private use and commerce, landcultivation, and the introduction of domestic animals have seriously influenced the environment of the island.

\section{METHODOLOGY}

Three cores (STM-1, STM-2, and STM-3) from different parts of the saline lagoon St. Michiel were collected in April 2000. The cores were recovered in 1-m sections using a hand corer. It is important to note that for this coring technique, there is a risk of contamination due to caving, especially at the base of each 1-m section. The diameter of the recovered cores is $4 \mathrm{~cm}$. Sediment samples, weighing on average $10 \mathrm{~g}$ and taken every $\sim 5 \mathrm{~cm}$ along the entire length of core STM- 1 and the 3 upper sections of core STM-2, were gently washed over a $63-\mu \mathrm{m}$ sieve. The residue was dried and examined under a stereomicroscope. Core STM-3 was not further considered for this study. 
The mineralogical composition of bulk sediments was semi-quantitatively determined by X-ray diffraction. X-ray diffraction analyses were obtained at the Institute of Earth Sciences in Barcelona (CSIC, Barcelona) using a Bruker Difractometer, Model D-5005, with a $\mathrm{Cu}$ tube, wave-length 1 $=1.5405$, Graphyte Secondary Monochromator, $\mathrm{KV}=40$ and $\mathrm{mA}=30$ as working conditions. Mineralogical information obtained from X-ray diffractions were used for semiquantitative determination of mineral phases present in the studied samples. The carbonate content, determined as the $\mathrm{CaCO}_{3}$ weight percentage, was measured at the Vrije Universiteit Amsterdam.

Radiocarbon samples were measured at the R. J. Van de Graaff Laboratory at the Utrecht University, the Netherlands.

\section{RESULTS}

\section{Sediment Lithology and Composition}

Core STM-1, from near the center of the lagoon, terminated at $500 \mathrm{~cm}$ below the sediment surface in weathered basement rocks and, thus, contains the entire sedimentation history in this part of the lagoon. Additionally, the presence of volcanic gravel and the characteristic bluish color of the sediment at the base of the core imply closeness to the "basement," the old volcanic valley floor. Core STM-2, taken close to the entrance, bottomed without reaching the basement at $550 \mathrm{~cm}$ and reached the depth limit of the coring equipment. Based on lithological characteristics and the sediment composition each core recovered from the St. Michiel lagoon can be subdivided into stratigraphic units (Figure 2).

\section{Core STM-1}

Unit $4(500-260 \mathrm{~cm})$ consists of mostly laminated sediments. Fine-grained laminae, 3-10 mm thick, are composed of concentrations of light-colored evaporites (gypsum) alternating with dark-grey aragonitic silt with some organic matter. Unit $3(260-175 \mathrm{~cm})$ is characterized by dark-grey aragonitic silt, very rich in charred plant remains, with locally occurring lenticular, 1-1.5-mm-large gypsum crystals (possibly of interstitial growth). At some levels, abundant gypsum crystals are present, many showing evidence of dissolution and mechanical wear and seem to be reworked. Horizons rich in fecal pellets of crustaceans are common throughout this unit. A 1-2-cm-thick layer, rich in fragments of bivalves, gastropods, and ostracod shells, accompanied by angular volcanic lithoclasts, occurs at $233 \mathrm{~cm}$. Unit $2(175-70 \mathrm{~cm})$ is composed of grey siliciclastic silt with gastropod-rich horizons at $150 \mathrm{~cm}, 138 \mathrm{~cm}$, and $105 \mathrm{~cm}$. Unit $1(70-0 \mathrm{~cm})$ is formed of violet, homogeneous, silt- to sand-sized siliciclastic sediment with a gastropod-rich horizon at $45 \mathrm{~cm}$.

\section{Core STM-2}

Unit $6(550-300 \mathrm{~cm})$ consists of light-grey bioclastic sand containing predominantly fragments of the calcareous algae Halimeda, as well as coralline algae, various gastropods and bivalves, echinoid spines, diverse foraminifera, and ostracod species. Above $400 \mathrm{~cm}$, the sediment grains show some abrasion of sharp edges and become darker. Unit $5(280-250 \mathrm{~cm})$ is composed of grey, bioclastic sand. Sediment is much finer than in the underlying unit and the faunal assemblage consists entirely of abundant fragments of fragile tellinid bivalves and ostracods. Unit $4(250-190 \mathrm{~cm})$ is characterized by light-grey carbonate silt to sand; in the lower part of this unit, a fine (milimetric), light-grey lamination occurs with some lithified carbonate crusts. Unit $3(190-140 \mathrm{~cm})$ is formed of yellowishgrey to dark-grey carbonate silt to sand. Unit $2(140-60 \mathrm{~cm})$ consists of dark-grey, clay- to silt-sized siliciclastic sediment. Gastropod-rich horizons occur at $122 \mathrm{~cm}$ and $85 \mathrm{~cm}$. In the lower part of this unit, there are darker layers which are rich in organic detritus and some charred plant remains. Unit 1 $(60-0 \mathrm{~cm})$ is composed of yellowish carbonate sand. 


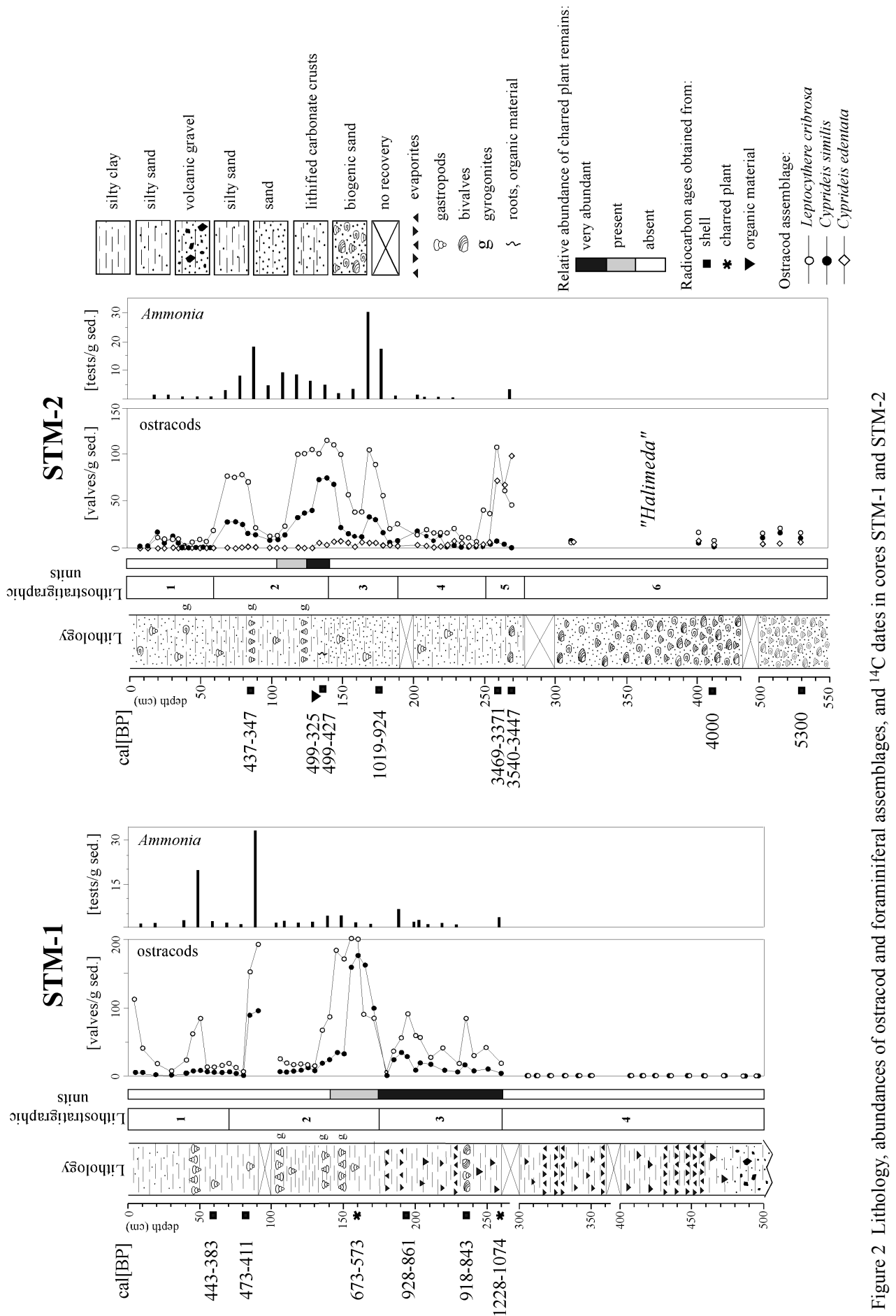


The biota represented in both cores (with exception of Unit 6 in core STM-2) include delicate, smooth, thin-shelled molluses, as well as foraminifers and ostracods. All species are benthic forms known as euryhaline taxa. Amongst the gastropods, species such as Pyrgophorus parvulus (Guilding), Pyrgophorus (cf. trabeata Weisbord 1962), Cerithidea costata (da Costa 1778), and Henrya morrisoni (Bartsch 1847) are the most common. Occasionally, landmolluscs as Ceciliodes sp. and Gastrocopta sp. are also present. Single gyrogonites, calcified oogonia of charophytea (macrophytic algae), occur occasionally in Units 1 and 2.

\section{Mineralogy}

Figure 3 shows the variation in the total amount of carbonate as well as calcite, aragonite, and dolomite from cores STM-1 and STM-2. The non-carbonate fraction of each sample corresponds to gypsum, siliciclastics, and clay minerals, which can only be expressed qualitatively from the XRD data. The detrital (allogenic) fraction is derived from weathering and erosion of drainage basin bedrock. It includes plagioclase and clay minerals, mainly smectites. Since the bedrock on Curaçao is formed of quartz-free rocks, it appears that quartz found in the studied cores is a result of atmospheric deposition. Examination under a stereomicroscope shows that calcite in core STM-2 is largely detrital in origin from locally reworked carbonates (limestone debris), especially at the upper part of the core. Other mineralogical components of the sediment comprise aragonite, gypsum, zeolites, and Ca-dolomite. Aragonite can occur as a product of direct precipitation from the seawater or as a detritus of the hard parts of certain organisms (e.g. corals, some molluscs). In core STM-1, aragonite occurs as granular aggregates, up to $1-1.5 \mathrm{~mm}$ in size, of very fine-grained crystals and, thus, is interpreted to be primary in origin, precipitated in response to supersaturated conditions in the water column. In core STM-2, however, examination under a stereomicroscope suggests that at least part of the aragonite can refer to biogenic carbonate debris. Zeolites occur as metamorphic minerals in the basalts of the basement (Klaver 1987), suggesting a detrital component, but they are also known to form from the alteration of silicic volcanic glass and tuffs in lacustrine deposits, particularly highly saline and alkaline environments (Deffeyes 1959; Mariner and Surdam 1970). Although Ca-dolomite is present in the surrounding limestones of the Seroe Domi Formation (Fouke 1994), the stratigraphically restricted occurrence in core STM-2 would suggest it to be primary, precipitated directly from the lagoon water or interstitial porewater, or from alteration (dolomitization) of a precursor carbonate mineral.

The most obvious changes identified in the sediments' composition of the cores is the increase in siliciclastic components - as plagioclase, quartz, and smectites - in varying degrees, from being absent or rare in the lower parts of the profiles to being very abundant in the upper part of the profiles (Units 1 and 2; Figure 3). Gypsum and aragonite content of the sediment shows significant inverse correlation with the siliciclastic components.

\section{${ }^{14} \mathrm{C}$ Chronology}

The chronology for the St. Michiel salina is based on accelerator mass spectrometry (AMS) ${ }^{14} \mathrm{C}$ dates of 11 well-preserved shells of gastropods, bivalves, and ostracods, one of organic material and two of charred plant remains (Table 1). The age-depth relation plot (Figure 4) shows obvious changes in sediment accumulation rates. In core STM-2, the reduction from $\sim 2.5 \mathrm{~mm} / \mathrm{yr}$ to $\sim 0.3 \mathrm{~mm} / \mathrm{yr}$ prior to about $3500-3400 \mathrm{BP}$ is thought to be due to an increased isolation or maybe even closure of the lagoon, which had a major impact on its hydrology. The period that follows is characterized by low accumulation rates, possibly with intervals of non-deposition. Around $1000 \mathrm{BP}$, the accumulation rate increases to $0.7 \mathrm{~mm} / \mathrm{yr}$, and at about $450 \mathrm{BP}$, dramatically exceeds 

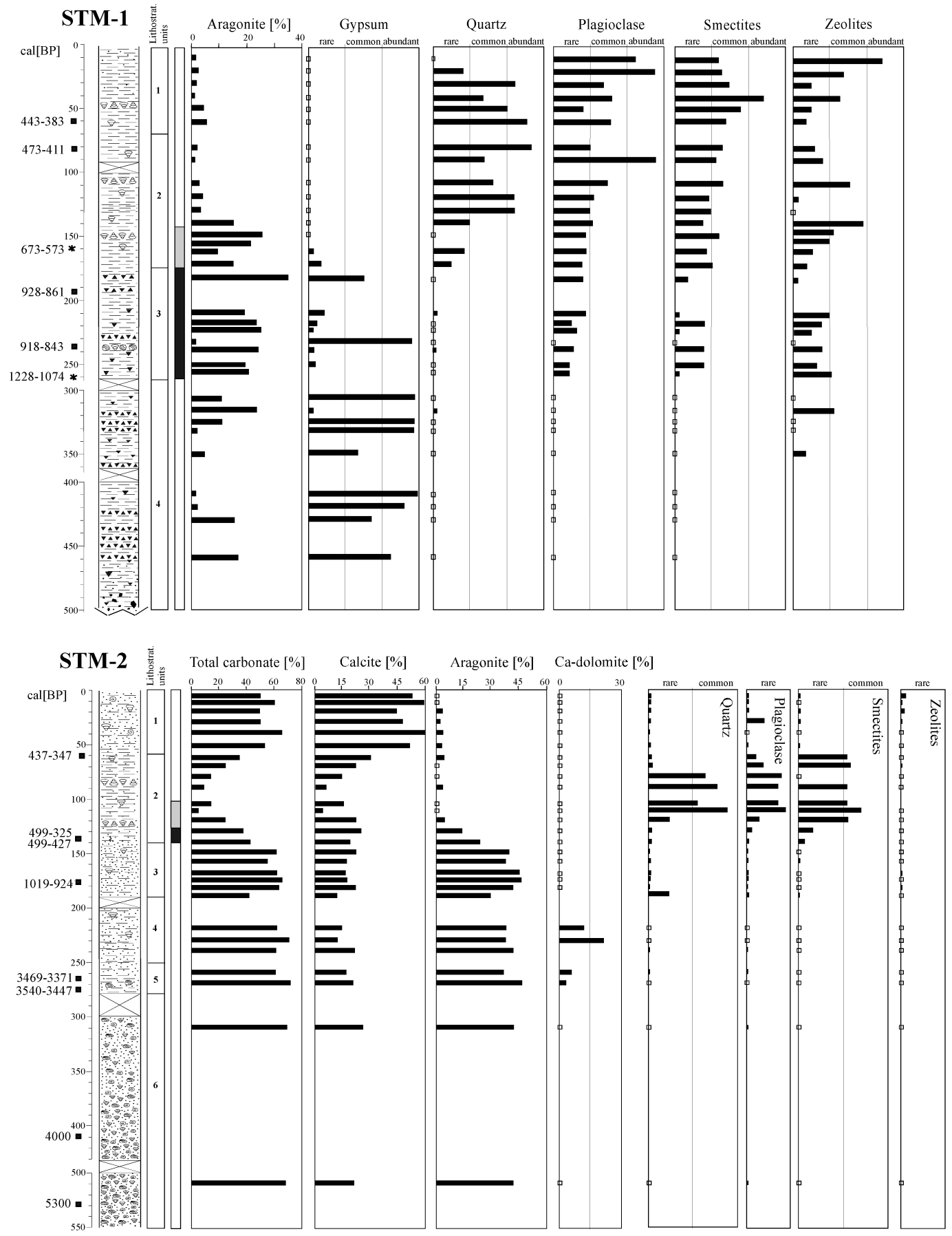

Figure 3 Stratigraphic variation in relative proportions of mineral phases in cores STM-1 and STM-2. Open squares represent absent data. 
$3 \mathrm{~mm} / \mathrm{yr}$. In core STM-1, the lack of suitable material for ${ }^{14} \mathrm{C}$ dating does not allow us to provide a chronology for the lower part of the record. If we assume that the site STM-1 is flooded when the sea level reaches $-5 \mathrm{~m}$ (the base of the core), then sedimentation rates of the lower $2 \mathrm{~m}$ of the core must be low, on average, $\sim 0.3 \mathrm{~mm} / \mathrm{yr}$. The detailed chronology of the upper 3 sections of this core yields fairly uniform, high accumulation rates of $\sim 2.4 \mathrm{~mm} / \mathrm{yr}$ from about 1200-1100 BP. However, two of the ${ }^{14} \mathrm{C}$ dates plot out of sequence, occurring too young to their stratigraphic position (Figure 4; Table 1). Since down-mixing of younger carbon is highly possible in our material due to the coring technique, the dates are considered less reliable age indicators. The base of Unit 3 in both cores is chronologically equivalent, dated to about $1100-1000 \mathrm{BP} .{ }^{14} \mathrm{C}$ ages of charred plant remains from core STM-1, from the interval of abundant charred plants, gives ages of about 1100 and $600 \mathrm{BP}$ and, thus, are evidence of eroded soil and forest clearing by Indians.

Table $1{ }^{14} \mathrm{C}$ and carbon isotope data for samples from St. Michiel lagoon. $\delta^{13} \mathrm{C}[\%]$ : abundance of ${ }^{13} \mathrm{C}$ relative to ${ }^{12} \mathrm{C}$ with respect to $\mathrm{PDB}$ reference. ${ }^{14} \mathrm{C}$ age $[\mathrm{BP}]:{ }^{14} \mathrm{C}$ age (Before Present), as calculated from measured abundance (normalized to $\delta^{13} \mathrm{C}=-25 \%$ ). Calendar age [cal BP]: intervals (1 $\sigma$ probability) using the program Calib3 (Stuiver and Reimer 1993) for the atmospheric environment (default), or (indicated by *) for the marine environment with $402 \mathrm{yr}$ of reservoir age. Conversion to cal $\mathrm{AD} / \mathrm{cal} \mathrm{BC}$ according to the relation $\mathrm{cal} \mathrm{AD}=1950-\mathrm{cal} \mathrm{BP}$, or cal $\mathrm{BC}=\mathrm{cal} \mathrm{BP}-1950$.

\begin{tabular}{llrrrr}
\hline Sample & Material & $\begin{array}{l}\text { Depth } \\
{[\mathrm{cm}]}\end{array}$ & $\begin{array}{c}\delta^{13} \mathrm{C} \\
{[\%]}\end{array}$ & \multicolumn{1}{c}{$\begin{array}{l}{ }^{14} \mathrm{C} \text { age } \\
{[\mathrm{BP}]}\end{array}$} & $\begin{array}{l}\text { Calendar age } \\
{[\mathrm{cal} \mathrm{BP}]}\end{array}$ \\
\hline Core STM-1 & & & & & \\
STM-1/56 & gastropods & 56 & -2.4 & $759 \pm 31$ & $443-383^{*}$ \\
STM-1/80 & gastropods & 80 & -4.7 & $790 \pm 36$ & $473-411^{*}$ \\
STM1/2/4 & gastropods & 140 & -0.6 & $686 \pm 36$ & $369-286^{*}$ \\
SM160 & charred plants & 160 & -14.3 & $704 \pm 32$ & $673-573$ \\
STM-1/195 & ostrac., gastr. & 195 & -5.5 & $1343 \pm 58$ & $928-861^{*}$ \\
STM1/2 & gastropods & 210 & -2.9 & $900 \pm 80$ & $582-448^{*}$ \\
STM-1 3/5 & bivalves & 235 & -1.2 & $1332 \pm 35$ & $918-843^{*}$ \\
SM255 & charred plants & 255 & -16.6 & $1227 \pm 39$ & $1228-1074$ \\
& & & & & \\
Core STM-2 & & & & & \\
STM-2/85 & gastropods & 85 & -2.9 & $751 \pm 36$ & $437-347^{*}$ \\
STM2/2 & organic mater. & 135 & -30 & $373 \pm 38$ & $499-429,364-325$ \\
SE 135 & gastropods & 135 & -5.3 & $824 \pm 49$ & $499-427^{*}$ \\
STM-2/2/3 & bivalve, ostrac. & 175 & 1.2 & $1430 \pm 50$ & $1019-924^{*}$ \\
STM2/3 & gastropods & 260 & -3.2 & $3549 \pm 48$ & $3469-3371^{*}$ \\
STM-2/3/5 & ostracods & 265 & -3.3 & $3601 \pm 39$ & $3540-3447^{*}$ \\
STM2/5/1 & gastropods & 410 & -0.7 & $3996 \pm 37$ & $4064-3934^{*}$ \\
STM2/6/3 & bivalve & 530 & 0.9 & $4990 \pm 60$ & $5432-5279^{*}$ \\
\hline
\end{tabular}

\section{DISCUSSION}

The coastal embayments on Curaçao are old river valleys flooded during the Holocene sea-level rise. The inlets of all bays of the island are narrow. However, that is insufficient to change these bays into hypersaline lagoons, as seen in the fauna of the Spaanse Water Bay (Klosowska et al. 2002), where the restricted range of salinities signifies the oceanic nature of the bay. Those bays that have developed into salinas are characterized by the presence of a natural barrier in front of the inlet con- 


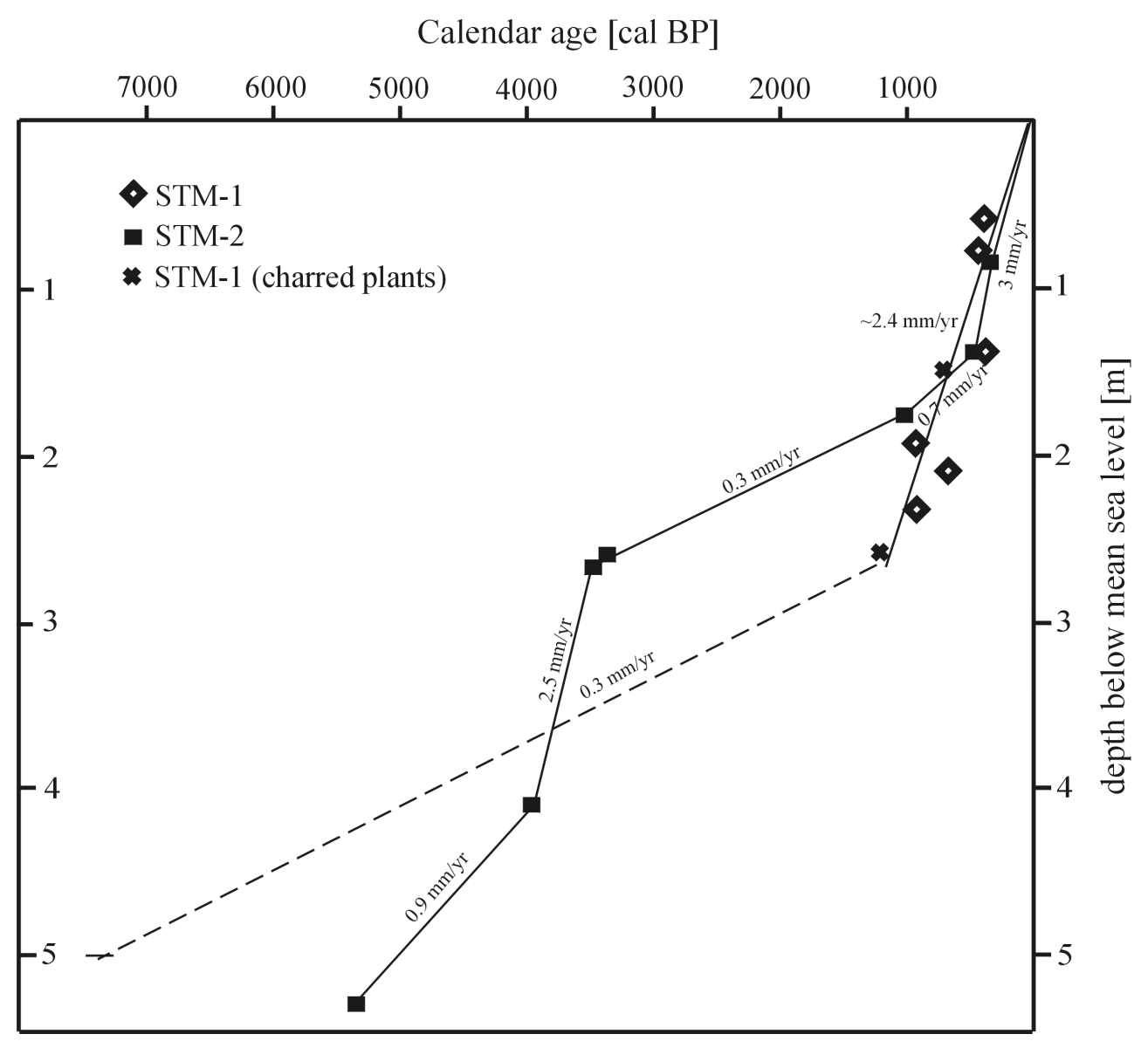

Figure $4{ }^{14} \mathrm{C}$ age-depth trend for the 2 cores of the lagoon St. Michiel

sisting of coarse-grained reef debris which severely restricts the connection to the open sea. Evaporites only accumulate in settings where concentrated brines generated by evaporation are not diluted by excessive influx of new solutions, either freshwater or seawater. In a marine setting such as the St. Michiel lagoon, precipitation of evaporites is controlled by evaporation (+outflow) losses exceeding inflow (seawater + rainfall + groundwater).

The STM-1 and STM-2 cores recovered from the St. Michiel lagoon demonstrate the record of a different evolution at different sections of the salina. Core STM-2, situated near the inlet, records the transition from a highly marine to a more restricted, euryhaline environment, whereas core STM-1, situated more inland, shows the reverse. The lower units of core STM-1 were formed in a highly evaporitic environment, changing to a less saline, euryhaline environment, similar to that of STM-2 in the upper units. This difference and the synchronicity of normal marine conditions at STM-2 and hypersaline conditions at STM-1 could be explained by a sill in paleomorphology separating the 2 sites during the earlier history of the bay. Bathymetric data of the St. Michiel salina do not exist, though the morphology of the adjacent areas strongly suggests that the NNW-SSE-running limestone ridge, about $100 \mathrm{~m}$ west of STM-2 (Figure 1), could form an efficient barrier/restriction to create a depositional environment suited for evaporite accumulation. 
The oldest recovered sediment, the biogenic Halimeda sand (Unit 6 of core STM-2) dated to about $5300 \mathrm{BP}$, was deposited in a coastal, semi-protected bay with a strong marine influence. Similar facies characterize the modern, shallow coastal areas of Spaanse Water Bay (Klosowska et al. 2002). From about $4000 \mathrm{BP}$ onward, accumulation rates notably increased, exceeding the rate of sea-level rise, resulting in shoaling. The sediment grains show abrasion of sharp edges, indicating reworking by waves or currents. At the same time, accumulation of sub-recent coral debris at the seaward margin (Figure 1) formed a natural barrier which increasingly isolated the bay from the open sea influence, and by about 3500-3400 BP, might have even closed the connection. With the closure/ isolation, sedimentation changed irreversibly, indicating deposition within a more protected, lower energy setting. Sediment became finer and the initial marine ostracod and foraminiferal assemblage in core STM-2 was replaced by an exclusively euryhaline biofacies (Figure 2). Low faunal diversity and an essentially monospecific foraminiferal assemblage, consisting of Ammonia tepida, imply ecological stress. Abundant tellinids and ostracods appear to represent possibly a phase of relatively stronger marine influence (Unit 5 in core STM-2). The distinct reduction of microfauna abundance following this interval suggests that conditions changed and were unfavorable for their survival or preservation, and the lithified carbonate crusts, which were found at some levels, may imply low to non-deposition intervals (Unit 4 of core STM-2).

During the deposition of Unit 6 in core STM-2 and normal marine conditions in this proximal part of the lagoon further inland at site STM-1, evaporites were precipitated (Unit 4 in core STM-1). Precise correlation is difficult due to poor chronology of the evaporite sequence. However, Unit 6 of core STM-2 occurs at the same depth as Unit 4 of core STM-1 and it is highly impossible that when Unit 6 was deposited, Unit 4 was a dry area. As mentioned above, a sill in paleotopography probably separated the 2 sites. Gypsum and aragonite precipitation is induced by increased evaporative concentration of the basin waters. Therefore, abundant evaporite minerals and the presence of laminae composed almost entirely of gypsum in core STM-1 indicate a prolonged period of a negative water balance and are highly suggestive of a very restricted connection to the open sea. The coarse gypsum crystals present in most of the samples imply stable growth in a subaqueous hypersaline environment (Warren 1982; Warren and Kendall 1985). Recorded layering and repeated changes in the relative abundance of aragonite and gypsum in the evaporite sequence result from variations in brine concentrations controlled probably only by climatic factors. Drier, more evaporative phases are recorded by gypsum-rich intervals, while aragonite-rich intervals signify periods with more precipitation. The scarcity of the siliciclastic detritus indicates that surface runoff during the evaporative phase was negligible.

At about 1100-1000 BP in core STM-2, a marked increase in microfauna abundance suggests a change to less extreme and more stable conditions. Similarly, in core STM-1 at the same time, the gradual disappearance of bedded gypsum, frequent occurrence of fecal pellets, and introduction of microfauna define a change to less evaporitic conditions (Figure 2). The presence of some prismatic-lenticular gypsum crystals still indicates stages of salinity increase. Peaks in ostracod and foraminifera abundance in both cores point to less saline intervals due to either fluxes of marine water through a poorly developed barrier and/or increased meteoric input. Episodic freshening of the salina waters associated with periods of increased precipitation and surface runoff may explain the recurrent bands of the gastropod Pyrgophorus spp., at times accompanied by angular lithoclasts and the occurrence of characin oogonia (gyrogonites), throughout Units 2 and 1 in both cores.

The lower part of Unit 2 in core STM-2 and the entire Unit 3 in core STM-1 are characterized by a high abundance of charred plant remains (Figure 2) which represent land clearance by forest burning. Practices such as cutting down of trees, charcoal burning, and clearing of land to set up plantations were thought to be most extensive during the Spanish and Dutch colonization of the island 
since the beginning of the 16th century (Terpstra 1948; Beers et al. 1997). The dated charred plant material at about 1200 and $600 \mathrm{BP}$ are older than this colonization, and land clearance by burning must have been a common practice of native South American farmers. A small increase in siliciclastic detritus in Unit 3 of STM-1 indicates a higher run-off in comparison to Unit 4 (Figure 3). This is probably also the result of Indian agricultural activities. A higher runoff would explain the change from completely evaporative to partly evaporative sedimentation.

Factors important in the induction of surface erosion of soil are likely due to the changes in drainage basin characteristics. Any disturbance in the drainage basin - as for example, deforestationchanges the fluxes, usually increasing them. Sediments from below Unit 3 in both cores were deposited prior to known permanent human settlements on Curaçao. Reduced rates of supply of clastic material, probably due to stabilization of the slopes, indicate a prolonged period of low-level human activity during which watershed vegetation remained largely intact and soil erosion was minimal. Abundant quartz, plagioclase, and smectites arrive just above the high concentration of charred plants interval (Figure 3), marking enhanced catchment erosion as an effect of land clearance and deforestation. Deforestation practices for agriculture and construction initiated already by Caquetíos Indians and further intensified by the Europeans, especially in the 17th and 18th centuries, destabilized soil cover in the St. Michiel salina's watershed and resulted in remarkably increased runoff of detrital fraction and sediment accumulation rates (Figures 3 and 4).

\section{ACKNOWLEDGEMENTS}

We thank Prof Juan Jose Pueyo for help with mineralogical analyses. The research is funded by the Netherlands Institute of Applied Geoscience (TNO-NITG).

\section{REFERENCES}

Beers CE, De Freitas J, Ketner P. 1997. Landscape ecological vegetation map of the island of Curaçao, Netherlands Antilles. In: Natuurwetenschappelijke Studiekring voor het Caraibisch Gebied 138:1-54.

Beets DJ. 1972. Lithology and stratigraphy of the Cretaceous and Danian succession of Curaçao. In: Natuurwetenschappelijke Studiekring voor Suriname en de Nederlandse Antillen 70:1-153.

De Buisonjé PH. 1974. Neogene and Quaternary geology of Aruba, Curaçao and Bonaire (Netherlands Antilles). In: Natuurwetenschappelijke Studiekring voor Suriname en de Nederlandse Antillen 78:1-293.

Deffeyes KS. 1959. Zeolites in sedimentary rocks. Journal of Sedimentary Petrology 29:602-9.

Fouke BW. 1994. Deposition, diagenesis and dolomitization of Neogene Seroe Domi Formation coral reef limestones on Curaçao, Netherlands Antilles. Foundation for Scientific Research in the Caribbean Region 134:1-182.

Klaver GTh. 1987. The Curaçao Lava Formation, an ofiolitic analogue of the anomalous thick layers $2 \mathrm{~B}$ of the Mid-Cretaceous oceanic plateau in the western Pacific and central Caribbean. In: Natuurwetenschappelijke Studiekring voor Suriname and de Nederlandse Antillen 119:1-163.

Klosowska BB, van Hinte JE, Troelstra SR, Laban C. 2002. Microfacies of Spaanse Water Bay, Curaçao (Netherlands Antilles), with special reference to benthic foraminifera. Journal of Coastal Research 18: 316-28.

Martis A, Van Olderborgh GJ, Burgers G. 2002. Predicting rainfall in the Dutch Caribbean-more than El Niño? International Journal of Climatology 22:1219-34.

Mariner RH, Surdam RC. 1970. Alkalinity and formation of zeolites in saline alkaline lakes. Science 170:977-80.

Meteorological Service of the Netherlands Antilles and Aruba. http://www.meteo.an.

Stuiver M, Reimer PJ. 1993. Extended ${ }^{14} \mathrm{C}$ database and revised Calib $3.0{ }^{14} \mathrm{C}$ age calibration program. Radiocarbon 35(1):215-30.

Terpstra H. 1948. De boomgroei op de benedenwindse eilanden in vroeger tijd. Mededelingen van Koninglijke Vereniging van Indisch Instituut 78:3-19.

Versteeg AH, Rostain S, editors. 1997. The archaeology of Aruba: the Tanki Flip site. Publication of the Archaeological Museum of Aruba 8. Publication of the Foundation for Scientific Research of the Caribbean Region 141:1-519.

Warren JK. 1982. The hydrological setting, occurrence and significance of gypsum in late Quaternary salt lakes in South Australia. Sedimentology 29:609-37.

Warren JK, Kendall CGStC. 1985. Comparison of sequences formed in marine sabkha (subaerial) and salina (subaqueous) settings - modern and ancient. American Association of Petroleum Geologists Bulletin 69:1013-23. 